\title{
A cultura musical erudita na universidade: \\ refúgio, resistência \\ e expectativas
}

JOSÉ EDUARDO MARTINS

\begin{abstract}
" Dir-me-eis: - Esta é a tua Ilha porque é nela que depositas e interiorizas todas as tuas geográficas inquietaçóes."
\end{abstract}

(Heitor H. Silva, poeta acoriano)

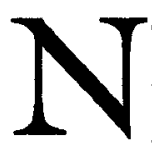
o amplo catálogo das culturas brasileiras, a cultura erudita das Artes situar-se-ia entre as que mais sofrem as transformaçóes generalizadas ocorridas no século XX. Constantes comuns a cada segmento das Artes revelam o filtrar diferenciado dos contínuos e cada vez mais acelerados choques por que passa a área, uma das mais criativas do pensamento humano.

A cultura erudita musical, em sendo um compartimento vivo, estático e volátil, materializado e fluido, tem toda uma série de elos que apenas dimensionam a interdependência. Sob outro aspecto, os limites fronteiriços entre a criaçáo erudita e a genuinamente popular - entenda-se nascida na interioridade de um povo, sem agentes voluntariamente pressionantes - podem ser tênues, havendo, por parte da primeira, incursōes profundas em território popular, a resultar sempre um enriquecimento.

O mergulho na cultura musical de povos outros, realizado pela etnomusicologia, traz em seu emergir muito mais do que a preservação, o descortino da contribuição para os estudos eruditos. A contrapor-se às culturas musicais erudita e popular, surgiria em progressão geométrica, mais precisamente na segunda metade do século, uma cultura oriunda da mass communication e que poderia, inclusive, ser entendida como uma cultura musical de massa, hoje no pleno trajeto da irreversibilidade. 
O confronto inevitável entre estas três culturas revelou-se, no Brasil, rigorosamente desigual e favorável à cultura musical de massa, por motivos vários, provocando o lento desestímulo à música erudita $\mathrm{e}$ destruindo a popular autêntica, atingidas pelo impacto da indústria cultural moderna. Para a música erudita ou de concerto, faz-se relevante buscarem-se determinados ingredientes sócio-político-econômico da sua trajetória, a partir do século XVIII, detendo-se mais precisamente em torno do nascimento da República.

O direito ao conhecimento artístico erudito atendeu, durante o Brasil Colônia, prioritariamente, à vontade do dominador que importava o bem cultural. Permaneciam o músico ou o artesão nascidos no país, atados ao seu limite colonial; e o conhecimento advinha da transmissão oral, visual, auditiva, manual e letrada de modelos oriundos da Metrópole. Não é difícil vislumbrarem-se, nos séculos XVIII e XIX, a música e a imaginária sacro-erudita ou popular nascidas para a realidade através de criadores mestiços. Emerico Lobo de Mesquita, Aleijadinho, Manuel Dias de Oliveira, Padre José Maurício e, tardiamente, Benedito Amaro de Oliveira, o Dito Pituba, ao conhecerem modelos aceitos como da maior erudiçáo, estabeleceram os critérios para as suas criaçóes, nas quais singularmente em superação, um atávico cultural do dominado está presente. Esse amalgamar do talento com a dificuldade para o saber pode ter sido o eixo paradigmático da criação ímpar. Alfredo Bosi (1992) nomeia arte de fronteira essa característica assimilatória e eruptiva, anteriormente entendida por Eduardo Etzel em sua extensa literatura sobre a arte sacra brasileira, quando criação seria a conseqüência do conhecimento limitado do modelo europeu por parte do criador, transformação por este realizada a partir de seu próprio acervo sócio-cultural-econômico, e da recepçáo criticamente balsámica por parte daquele que cultuava e a quem a imaginária era destinada. Poder-se-ia estender os critérios para a música, sacra em questáo.

Uma outra realidade originária da mesma interligação dominador-dominado verifica-se no ensino e na prática da música erudita nos centros urbanos, desde o Brasil-Colônia. Se a vinda de D. João VI possibilitaria a abertura receptiva à resultante de parte da criação européia entenda-se via cultura ibérica - a manutenção conservadora durante o século XIX daquele fluxo cultural, explicar-se-ia através de produção nativa de qualidade, podendo-se detectar, em certas produçóes, a relação mestre-aluno, mas numa essencialidade preferencialmente ingênua, repetitiva e circunstancial. O ensino musical no Brasil assiste primeiramente no Rio de Janeiro, com a fundação do primeiro Conservatório de música, aos 13 de agosto de 1848 , do tímido ao crescente surgimento 
de escolas específicas nos centros urbanos mais desenvolvidos. A pianolatria de que fala Mário de Andrade foi um fenômeno típico brasileiro, que perdurou por mais de um século e atendia fundamentalmente à possibilidade de ascensão cultural por parte de uma burguesia plena de rígidos controles. Como exemplo, em meados do século XIX, o Brasil colocava-se entre os cinco primeiros países importadores de partituras francesas. Grande quantidade referia-se a peças para piano, constituídas de danças de salão ou transcrições para piano de aberturas e árias de óperas.

Àqueles que da segunda metade do século XIX às primeiras décadas deste permaneciam no magistério, preparando geraçóes igualmente enraizadas, divulgavam um repertório circunstancial, transitório, sacralizado no gênero e fragilizado na Europa, propiciando à classe dominante a ilusão da cultura européia. Os programas dos saraus ou das apresentações públicas de professores e alunos permeiam repertório importado, no qual raros são os nomes de compositores que permaneceram pela qualidade, assim como uma produção nativa e essencialmente do modismo. Frise-se, muitos dos professores que corroboraram a edificação de um ensino musical no Brasil eram originários da Europa, aqui aportando como integrantes de troupes de teatro musical, que se fixavam nas cidades na medida das tournées prolongadas pelas urbes brasileiras.

Sob outro aspecto, fazia-se música nos saraus familiares, ratificando o poder dos patriarcas que os realizavam; solidificando ainda mais a presença do professor, o vcículo indispensável que possibilitava o resultado cultural; mediocrizando o compositor nativo condenado à música circunstancial. A criação autógena via-se, pois, confinada à imitação dos modelos vigentes. $O$ Arquivo da Biblioteca Nacional do Rio de Janeiro está pleno de exemplos quantitativos do importado convivendo sem atritos com a produção brasileira.

De um nítido amadorismo vigente surgiam, por vezes, personagens que, sufocados pelo ambiente rarefeito, encontraram no Exterior as estruturas básicas para a criação. Carlos Gomes, Henrique Oswald, Alberto Nepomuceno e, adentrando o século XX, Villa-Lobos, Francisco Mignone, Camargo Guarnieri, Cláudio Santoro são alguns autores expressivos - sem contar a quantidade de intérpretes preferencialmente pianistas - que viajaram à procura do conhecimento.

Se o pequeno passo voltado a uma cultura musical genuinamente brasileira é dado em torno da passagem do século, foram, contudo, os anos $\mathbf{2 0}$ que conduziram à oficializafáo do fazer música nacionalista, circunscrito a parâmetros do pensar nacional e do aplicar ritmos, contor- 
nos melódicos e terminologia nativos. Apesar das forças muitas vezes aparentemente telúricas que os prendiam ao Brasil, os nacionalistas Villa-Lobos, Francisco Mignone e Camargo Guarnieri contataram, in loco, técnicas composicionais na Europa. Aos citados, juntem-se os nomes posteriores que lá, preferencialmente, apreenderam e filtraram técnicas e pensamento estético em ebulição. Gilberto Mendes, Willy Corrêa de Oliveira, Almeida Prado e tantos outros que não fecharam olhos nem taparam ouvidos à sedução alienígena.

Um problema outro se instalaria nas mentalidades dos que ensinavam e faziam música. No Rio de Janeiro, como exemplo, a categoria docente acostuma-se inicialmente no Conservatório de Música e, em 1890 , com o seu sucedâneo - o Instituto Nacional de Música - à perpetração de vícios advindos do inter-relacionamento classe dominante-música, burocracia-músicos dirigentes. O professor, por seu turno, submisso ao dominador antes do ingresso no estabelecimento de ensino, sob a égide da instituição, tem a aparência da liberdade nas relaçóes com a administraçāo. Da sujeição à atividade entendida regularizada, professores escolhidos exerceriam funções burocráticas sem o saber necessário. Outra dimensão emerge na convivência nem sempre tranqüila entre os docentes e a administraçâo. Um corpo discente socialmente educado à obediência, basicamente não interferia.

Em 1903, após uma permanência acima de três décadas na Europa, Florença notadamente, Henrique Oswald recebe o convite do Barăo do Rio Branco a fim de dirigir o Instituto Nacional de Música do Rio de Janeiro, em conseqüência do falecimento de Leopoldo Miguez. Da euforia inicial, Oswald deságua para a total descrença em ver aplicados na Instituição conceitos mais modernos. Três anos após, no absoluto desespero administrativo, o compositor dirige-se a Munique onde, aos 21 de março de 1906, participa de um recital camerístico dedicado às suas obras. Houve sucesso. Dois dias seguidos ao concerto, obscrvava em seu diário: "É horrível para mim o dever de retornar ao Rio, naquele inferno em que tanto sofri! Só Deus sabe o que lá me espera" (1).

A frase de Henrique Oswald reflete não apenas as angústias pessoal e profissional, mas traduz uma realidade na relação professor-burocracia, que se manteria durante todo o século $\mathrm{XX}$ a transparccer agravantes irreparáveis. Em outro trecho do diário, Oswald comenta um perfil da juventude sem aspiraçóes no Brasil de entâo. Acrescente-se que o ensino musical público ou privado no país estava basicamente voltado a uma formaçáo cultural incipiente e destinado a uma mocidade que, em sua maioria, desistiria de seguir o caminho musical. Ainda hoje, conservatórios sobreviventes espalhados pelo vasto território, repetem ad infi- 
nitum disciplinas sem renovação a alunos que encontram na prática musical ou a tentativa da profissáo, ou a ascensão do que se rotulou cultura genérica.

A pianolatria por Mário de Andrade aludida como prática essencialmente nacional evidenciava a permanência, corroborada pela considerável presença, de professores de piano estrangeiros que transmitiam conceitos defasados, comparando-se aos praticados na Europa.

Na primeira metade deste século, preferencialmente, a prática de instrumentos como piano e violáo - ainda hoje os mais solicitados formavam os parâmetros de uma cultura individualizada. Somou-se, a partir do Governo Vargas, nos anos 30, o fortalecimento do canto orfeônico de cunho ideológico e levado à escola pública. A abertura de um leque de opçôes, tanto nas disciplinas instrumentais quanto teóricas, mostrava-se, contudo, complexa na competência. De um lado, professores de conservatório, que anteriormente aprenderam de alguns mestres estrangeiros radicados no Brasil, ou não, e muitas vezes recrutados endogenicamente nas próprias cidades onde o estabelecimento de ensino se instalava; de outro, fiscalização oficial nascida dos mesmos equívocos, contendo em seu cerne a não-renovaçáo conceitual e entendendo a troca de favores, essa praga nacional, como um ato natural. A cada geraçăo foi transmitido um saber menos eficiente, desconhecedor tanto da elementar didática atualizada, como de um repertório náo ventilado. Muitos dos estabelecimentos particulares manter-se-iam em mãos de uma mesma mentalidade gerencial e pedagógica durante geraçōes, acarretando a mais absoluta indiferença pela matéria música, por parte de professores e alunos.

Seria necessário frisar que toda a problemática professor-aluno nasce do fato de ser a música, entre as artes, aquela que se estrutura, na maior das vezes, em plena precocidade. O compositor belga André Souris já observara: " (...) os estudos musicais são, distanciadamente, os mais esterilizantes. De um lado, eles canalizam as faculdades intelectuais em jogos abstratos de complicação gratuita" (Souris, 1976). Tenha-se como referência a necessidade do prematuro estudo de solfejo, da percepçáo, do aprendizado físico-mecânico instrumental, que podem estiolar nos primeiros anos de idade vocaçóes autênticas.

Para o instrumentista, parte da infância é, obrigatoriamente, destinada ao estudo específico, o que torna uinica a complexidade musical. A excepcionalidade da área musical caracterizar-se-ia pelo exercício precoce da elementaridade. Souris (1976) continua: "Na literatura, na pintura, na escultura, não existe senão um autor e uma matéria, enquanto que 
para a música existe um autor, uma escritura, um intérprete e uma matéria. Poder-se-ia dizer que o mesmo ocorre com o teatro, mas aí também há uma distinção a ser feita. É que o teatro usa palavras, e o sentido das palavras é independente da sua sonoridade. Sem dúvida, esta independência é maior ou menor de acordo com o texto, mais ou menos poético. Mas, tratando-se de música, não há senão a sonoridade, a significação; o conteúdo da música não pode, de maneira nenhuma, isolar-se da forma sonora. A significaçáo é imanente ao som puro. $O$ sentido é o som".

Até aproximadamente meados do século $\mathrm{XX}$, o divisor de águas se fazia visível, a salientar ou a preparação inadequada por parte dos conservatórios de quantidade de alunos dos quais uma parcela apreciável dedicava-se à música na aspiração professoral - entenda-se sempre mais desatualizada - ou a evidenciar àqueles alunos oriundos de famílias mais abastadas, o descortino competente das aulas particulares oferecidas por considerável parcela de professores estrangeiros, que poderiam abrir o caminho da carreira para o virtuose. Destacava-se o domínio elitizado, propiciando aos talentos originários de famílias ricas, sempre a melhor qualidade do ensino.

Considere-se que as orquestras do eixo básico Rio-São Paulo mantinham em seus quadros, até recentemente, índices percentuais acentuados de músicos notadamente europeus, os quais cclaboraram na formação essencial daqueles que os sucederiam nos agrupamentos sinfônicos. Neste mister, igualmente, pareceria claro que a qualidade não foi sobrepujada pelos discípulos, possivelmente por causa do ingresso precoce destes nas orquestras, devido não só à necessidade de sobrevivência, como à quase inviabilidade, para a maioria, de um aprimorar fora de nossas fronteiras.

Ao declínio dos Conservatórios estabelece-se a aceleração, nas últimas décadas, dos cursos superiores de música nas universidades. Destes, poucos os que mantêm em seus corpos docentes a qualidade necessária. Clarifica-se a distorçáo e o desequilíbrio. A cada ano nota-se a queda cultural e musical dos vestibulandos, o que denota uma problemática mais profunda. Número considerável dos alunos provêm dos conservatórios e estes são cada vez mais fragilizados, tendendo ou ao desaparecimento ou à total descaracterização, na angústia da sobrevivência. Há pouquíssimas exceçóes entre os conservatórios e escolas de música no país, oficiais ou não, que não ultrapassam número ínfimo. A excepcionalidade ficaria por conta da resistência competente à mediocrização. 


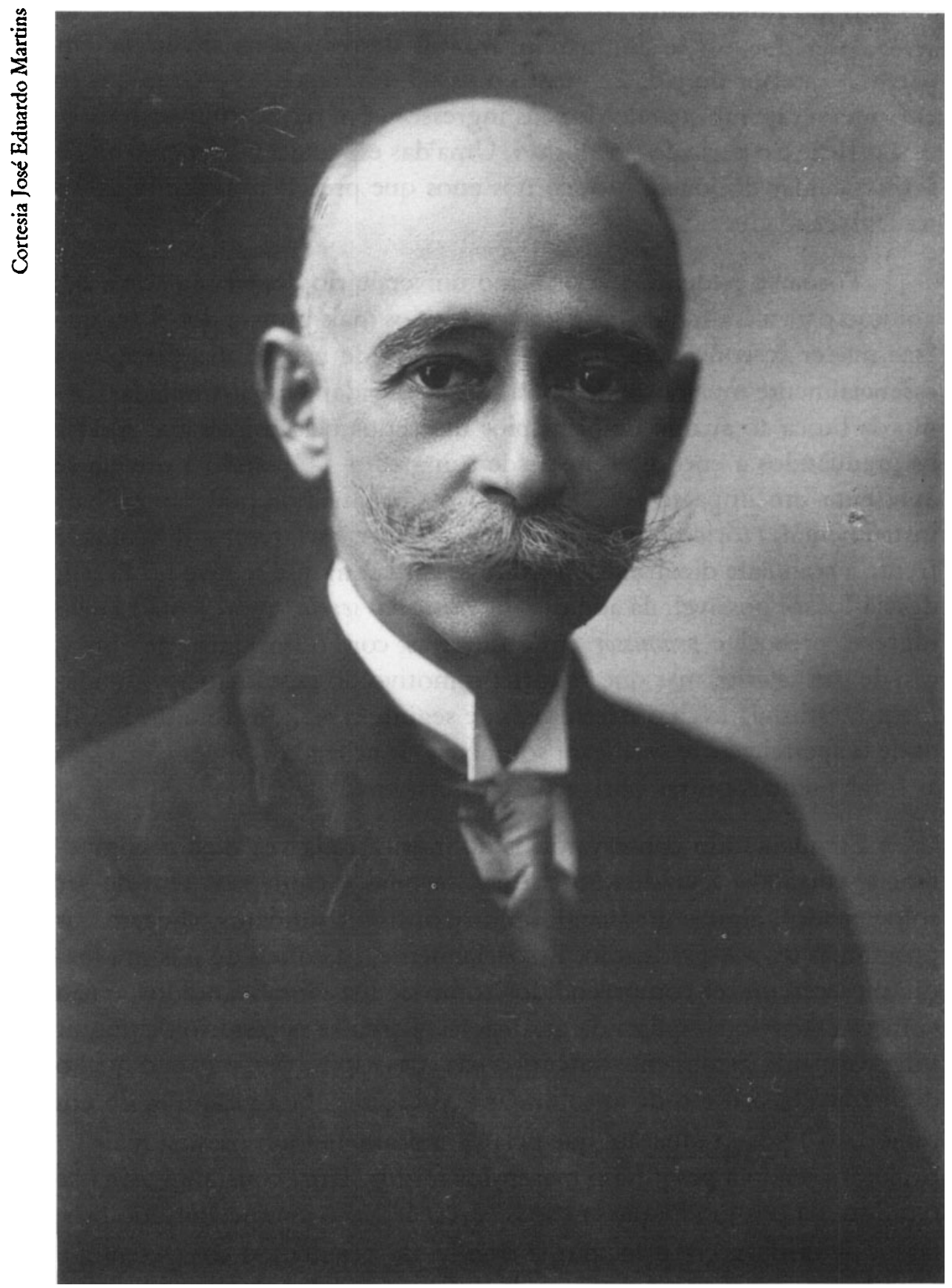

Governo e iniciativa privada estariam voluntarianentc propensos a resgatar compositores eruditos da qualidade de um Henrique Oswald (1852-1931)? 
A graduaçăo, num departamento universitário de música, tem o papel que a este não deveria ser atribuído, o de suprir as deficiências do ensino no conservatório, o que resulta na tentativa de recuperaçáo de um período fundamental, mas irremediavelmente perdido. Poder-se-ia acrescentar que, ao se graduarem, muitos destes jovens situam-se em patamar inferior do conhecimento musical, nivelados ao estágio que se entenderia esperar quando de seus ingressos. Em termos universitários, essa certeza é o peristilo do abismo. Uma das esperanças do ensino ainda seria o cuidar do jovem músico nos anos que precedem o seu ingresso na Universidade.

Torna-se evidente que o ensino universitário deveria ater-se à devoluçáo para a comunidade de graduandos os mais preparados. Para que esse mister se concretize, haveria a necessidade nấo só das disciplinas essencialmente musicais e de outras áreas, devidamente assimiladas, como da busca ao auxílio de princípios utilizados pela psicologia. Ajudar os graduandos a encontrarem desde o ingresso - quando a dúvida se apresenta um impasse - o caminho o qual melhor poderáo trilhar: instrumental, teózico, regência ou composiçáo; esclarecer a dificuldade frente à realidade dicotômica musical absurda em que se vive no Brasil; desviá-los, se possível, da audição do canto das sereias representado pelo ingresso precoce e promissor em orquestras, com o fim único de obtenção de um salário, mas que se torna o motivo do desvio ao aprofundamento; estimulá-los a obterem bolsa e seguirem estudos fora do Brasil, onde $o$ aperfeiçoar se verificará sob níveis de acirrada competição, essas as fundamentais outras obrigaçóes professorais.

Freqüentando conservatórios de música cada vez menos competentes, cursando a graduação em que lacunas e equívocos têm de ser solucionados, alguns graduandos, entre outros candidatos, chegam aos programas de pós-graduação. Essencialmente, os cursos de pós-graduação mereceriam ser compreendidos como de Estudos Avançados, e não como a extensáo simplista da graduaçáo. Torna-se necessário distinguir um postulante geralmente autêntico nas suas aspiraçóes, e para o qual o desiderato básico é o de aprofundar a vocaçáo para a pesquisa, de um candidato à pós-graduação, que nela vê unicamente um passo a mais na titulação, sendo a pesquisa o maior dos fardos. Uma constante torna-se o reflexo da pós-graduação em suas várias áreas. A competência do professor determina, em princípio, a escolha do orientando competente, $\mathbf{e}$ quando essa regra náo é expressa, haveria a possibilidade de negligência por parte do orientador, mesmo o mais capacitado. Sob outra visão, quão significativo ainda se evidencia o clientelismo, essa erva daninba, que inviabiliza o aprofundamento abissal, focaliza a superficialidade; 
estimulando a mediocridade que está sempre à procura dos espaços universitários, a instalar o altar onde o ídolo adorado é a funçăo burocrática, frise-se, entendida quando desculpa única ao náo-pensar e ao não-fazer intelectuais.

Apesar das realidades diferenciadas, poder-se-ia aplicar para a Universidade brasileira os conceitos de Jacoby (1990), ao constatar que parte considerável da intelectualidade americana refugiou-se nas Universidades. Sob outro enfoque, Alfredo Bosi entende uma cultura erudita concentrada na Universidade "(...) versando o mais das vezes, sobre materiais secundários ou terciários, já trabalhados pela literatura específica dos temas. A Universidade é o lugar em que a cultura se formaliza c se profissionaliza precocemente. Tecnicista, ou mesmo crítica, essa cultura chega logo à cunhagem de fórmulas e se nutre dessas fórmulas até que sobrevenham outras que as substituam. Trata-se de um universo que produz discursos marcados, tematizados. Cultura na Universidade é falar sobre alguma coisa, de modo programado" (Bosi, 1992). As Artes na Universidade têm dado exemplos dessa preservação erudita, mas igualmente da autêntica cultura criadora intramuros através de seus compositores, artistas plásticos e autores de textos teatrais.

Se ensino, prática e pesquisa musicais adquirem o peso absoluto na Universidade, a esta fica reservada nesse direcionamento uma das estruturas que sustentam a preservaçáo da memória: o estudo e a publicação do resultado do debruçar sobre textos musicais e partituras do passado e da contemporaneidade. A todo o desinteresse público ou privado pela memória musical, no que se refere a gravaçóes ou publicaçóes, um acanhado mas promissor espaço é auspiciado pela Universidade. A veiculação do pensar e da análise musicais tem desaguado nas significativas revistas especializadas em pouquíssimas universidades públicas e cujo número não ultrapassa um dígito, comparadas às dezenas ou centenas existentes em alguns países de pesquisa de ponta. Contudo é um avanço.

As lacunas ainda não preenchidas a contento, referem-se à gravação de discos e $\mathrm{CDs}$, ou à ediçăo de partituras. $\mathrm{O}$ desmonte da Funarte tradicionalizada, pelo governo Collor, apreendeu a resultante do irracionalismo. A memória fonográfica fazia-se preservar lenta, mas precisa, e um passado da maior importância, assim como o presente qualitativo, estavam sendo registrados. As gravaçóes, edição de livros e partituras cm pulsação hibernal, mantinham, na essência, o ritmo atestatório da existência. Da verba miserável do atual governo à Cultura, uma minimigalha deverá ser destinada à nova Funarte. Parece óbvio acreditar que os padróes anteriores, já pequenos, não serão mantidos. Não havendo qualquer interesse da iniciativa privada em registrar música erudita - exce- 
ção a alguns álbuns para brindes natalinos - caberia à Universidade empreender esse desiderato, mesmo que em perspectivas experimentais, e alguns exemplos significativos já se evidenciam. Quanto às partituras, a possibilidade inequívoca e única de sobrevivência da criaçâo musical desapareceu quase que por completo. Não mais se editam partituras no Brasil. Mesmo os mais representativos compositores brasileiros já desaparecidos e coetâneos, como Carlos Gomes, Henrique Oswald, Alberto Nepomuceno, Francisco Braga, e os posteriores Villa-Lobos, Francisco Mignone, Camargo Guarnieri, Cláudio Santoro entre outros, em período áureo, tiveram editadas parcela inferior à ponta de um iceberg. A constataçáo leva à certeza de o universo criador musical brasileiro, na sua quasc que incomensurabilidade, continuar ignoto. $O$ que dizer sobre a produçáo contemporânea, esta mergulhada no básico naufrágio edito--. rial específico? Exemplo significativo de exceçáo é o da Universidade Federal da Bahia, ao participar da publicação de obras da maior importância dos compositores baianos. Nessa área das partituras, torna-se atribuição da Universidade, como última alternativa, o destinar minguadas verbas para a ediçáo composicional menos industrial, isto é, via computador, acarretando gastos menores.

Em outro compartimento, situa-se o impasse às importaçōes de instrumentos isentas de taxaçóes. Por mais de um século, o Brasil importou livremente instrumentos de alta qualidade. A produçáo instrumental brasileira impede, hoje, um fluxo natural dessas importaçóes. No que se refere ao piano, fábricas brasileiras produzindo instrumentos sem a qualidade básica existente nas indústrias dos maiores fabricantes internacionais, inundam o país com pianos que não resistem a qualquer comparação séria e que, na essência, desestimulam até o bem tocar.

Ensino, pesquisa, o pensar musical no todo, apesar das maiores dificuldades, seguem o caminho prioritariamente na Universidade. $O$ fazer musical dependeria de fatores outros que não os somente universitários. Parcela considerável dos que fazem música erudita publicamente, intérpretes, regentes, jamais ocupou bancos universitários e, nem por isso, deixam de ser bons músicos. A performance precoce do virtuose, o espaço prematuro ocupado pelo músico de orquestra, inviabilizam inúmeras vezes a freqüência ao banco universitário.

Referentemente à prática musical, verifica-se que a apresentação. pública fora da Universidade só pode ser quantitativa e diversificadamente mais abrangente. Basicamente, o público originário das várias camadas sociais que freqüenta o recital ou concerto público nas cidades, quase desconhece o pensar e o fazer musicais em ebuliçáo na Universidade. As perguntas prioritárias a serem formuladas devem se referir à situ- 
ação atual e futura da performance da música erudita no Brasil: há espaço ainda para a divulgaçâo da música de concerto? Quais as causas de uma sensível diminuiçáo do público frente a determinadas apresentaçóes de concerto erudito? Poder público e poder econômico estariam interessados em manifestaçóes elitistas? Náo estaria a mídia atendendo a interesses outros que conflitam com a erudição? Não se posicionariam certos músicos de concerto, qual aves de rapina, preparados unicamente para a concessão a todas as espécies de favores na necessidade imperiosa da sobrevivência comprometida? Qual a esperança de um jovem músico quanto ao mercado de trabalho, no Brasil de hoje, totalmente distorcido?

A ascensão da cultura de massas tem sido um fator preponderante para o decréscimo da cultura musical erudita ou de concerto. A indústria cultural moderna, em aceleração crescente, apreenderia todos os ingredientes da mass communication, e visaria o lucro como desiderato maior, antepondo-se, sob outro prisma, a qualquer lógica essencialmente cultural tradicionalizada. Enfraquecendo os valores da música erudita, um status quo instaura-se a partir dos anos 60, esparramando os tentáculos e fazendo emergir uma cultura alienígena, transformada e mistificada no Brasil, atingindo manifestaçóes musicais de índole popular, contaminando-as, destruindo-as e erigindo comportamentos outros. Essa ascensâo instaura-se nos mais diversos níveis, assistida pela classe musical erudita incrédula e despreparada, quase que totalmcnte esquecida pelos Poderes público e privado, ambos buscando números quantitativos, diferentemente focados em suas especificidades nítidas.

Poder-se-ia argumentar que igualmente na América do Norte, na Europa ou no Japáo, gêneros não nacionais massificantes, quando aplicados em determinado país, ocupam espaços decisivos. Contudo, a sólida estrutura erudita preserva o ensino, a prática e o pensar musicais, resultando fluxo contínuo da criação sacralizada e contemporânea. Nos países desenvolvidos, o segmento da indústria cultural direcionado ao erudito estimula a gravação, edita partituras, fomenta a ediçáo crítica, visando a excgese complcta da obra de um autor ou período, sempre em escala crescente. A performance obedece à tradicional programaçáo, alcançando índices públicos compatíveis.

Destruidora tem sido, no Brasil, para a cultura musical erudita, a participação do Estado e, sobremaneira, da iniciativa privada. Apesar de uma aparente dicotomia, simbiose estranha entre eles se realiza, ao despontarem, tantas vezes, escusos interesses. $O$ avanço crescente da cultura de massas resulta na obrigatoriedade do lucro de todo um sistema conhecido no Brasil como selvagem, mas que, pelas profundas distorçóes, 
assumiria a irracionalidade. $O$ capital, privilegiando o objeto a ser vendido, estimula a veiculação viva do mito - esse personagem de venda, apesar de jamais assim sentir-se - o que facilita junto ao consumidor o produto a ser tragado. Gêneros autênticos musicais grosseiramente mistificados, como o sertanejo, o rock, a MPB, o bolero - revisitado - são periodicamente substituídos, descaracterizando-se sempre para pior. Os personagens igualmente se sucedem, e o ídolo de hoje será, num futuro breve, o esquecido de amanhá. É o mesmo processo que se verifica com o produto da indústria, sempre descartável; hoje o mais extraordinário dos detergentes, alguns meses após, o mais fabuloso dos detergentes; hoje o automóvel mais rápido e cômodo, amanhã o automóvel mais veloz e aconchegante.

Viu-se igualmente, nestas últimas décadas, a música de concerto bipartida entre a rotina sem tentativas competentes de, no mínimo, o arejamento, e a experimental, não despertando por seu conteúdo hermético e intelectualizado - e destinada a um público especial - interesse do poder econômico. Sob outro prisma, a música assentada em sua tradição tem despertado o nítido envolvimento das grandes empresas, quanto a patrocinar eventos com a participaçáo internacional de orquestras e solistas altamente conhecidos. O comprometimento governo-iniciativa privada-mídia torna-se cristalino, pois nesses acontecimentos, bancos estatais e organizaçóes não-governamentais de vulto sustentam, com somas elevadas, essas visitas. Empresariadas por entidades culturais - a cada dia mais distantes do público de menor poder aquisitivo, mas que realmente assistiria com entusiasmo - as apresentaçóes das sinfônicas, conjuntos ou solistas internacionais são presenciadas pela classe abastada que, em grande parte, comparece pelo status social do acontecimento. Uma pesquisa elementar colocaria em evidência o absurdo desperdício de empresas estatais dispendendo importâncias enormes para o evento apenas, essa ilusão do perene. A mídia, atenta ao pleno envolvimento financeiro dessas promoçóes, veicula amplamente a pré-chegada dos artistas internacionais, os bastidores, as entrevistas sempre supérfluas, o evento e mais nada. Um melancólico silêncio se abate, dias depois, sobre o espetáculo alienígena que não fíncou raízes, não difundiu a cultura musical erudita a quem dela necessita, repisou repertório em sua caminhada mitomânica. A qualidade pouco ou nada representaria. Ela seria considerada como a própria superficialidade. Dois exemplos: um primeiro de orquestra internacional - a do Maggio Musicale Fiorentino - que, a convite dos poderosos, teve parte dos seus integrantes recrutados momentos antes do vôo destinado aos eventos abaixo do Equador. Num segundo, o maior banco público do Estado, que teria missão prioritária, quando da promoção de eventos musicais, de incenti- 
var a qualidade do músico nacional, custeou amplamente a Orquestra Filarmônica de Israel para apresentaçôes de circunstância. O que restou? A evaporação da performance e dos dólares; mais acentuadamente desamparado ficou o músico brasileiro.

A tipificação da aplicaçáo governo-iniciativa privada fica clara na destinação de verbas para festivais de música de concerto. No momento, dois exemplos: o Festival de Campos do Jordáo e o Música Nova. No primeiro, governo estadual prioritário e empresas particulares dedicam quantias assombrosas para a nossa realidade, consumidas no espaço de um mês, basicamente em espetáculos. Apesar do desdobramento para cidades não de veraneio, o perfil do público que recebe os eventos mais dispendiosos é basicamente o mesmo das platéias abastadas, que assiste aos concertos internacionais em São Paulo e Rio. Perfil este de ouvinte que viaja anualmente ao Exterior, mas que em Campos do Jordão assiste gratuitamente aos concertos. Aí uma nítida malversaçáo. $O$ evento se volatilizando com o fim do evento, tornaria desnecessária a aplicação de somas tão elevadas.

De outra parte, o Festival Música Nova, que se realiza há mais de trinta anos em Santos e, posteriormente, São Paulo, Campinas e Ribeirão Preto, respectivamente. Este não se extingue, pois é mostra fundamental da criaçāo contemporânea erudita. Recebe do governo estadual mínima ajuda e rigorosamente quase nada da iniciativa privada, apesar dos nomes internacionais que ao Festival comparecem. Subsiste pela teimosia de seus dirigentes e pelo apoio da Secretaria Municipal de Cultura da cidade de Santos. A cada Festival findo, novos talentos criativos surgem, e é estimulante o conhecimento da produçảo contemporânea a mais hodierna.

Seria possível acreditar que, em termos brasileiros, um choque estético tenha sido uma das causas da acomodação da consciência de uma mídia pragmática. Esta teria entendido os apelos do público quantitativo às manifestaçóes que surgiam sob a égide popular - Bossa Nova, MPB, Tropicalismo, Jovem Guarda - , descartando lenta mas seguramente, o elitismo reforçado pelas vanguardas eruditas, responsável, em parte - mercê da postura egocêntrica de muitos compositores - pelo distanciamento dos ouvintes. Quão não foram os autores da música contemporânea erudita que, a partir da segunda metade do século, escreveram para o próprio gozo estético, ignorando por completo a avaliação da platéia? O empresariado astuto teria optado, já nesse período, pela quantidade numérica do público.

Frise-se que, até o período dos anos 60 , música popular e música 
de concerto ocupavam espaços basicamente idênticos. A música erudita perpetuava o repertório sacralizado praticado por brasileiros e músicos estrangeiros que visitavam o país, enquanto a música popular conservava a aceitação junto às várias camadas sociais. Corroborava o equilíbrio, a presença de inúmeros críticos de música de concerto nos principais jornais de uma cidade como São Paulo. O Estado de S. Paulo, Folba da Manbã, Folba da Noite, Diário de S. Paulo, Diário da Noite, A Gazeta, O Tempo, Correio Paulistano, Fanfulla, Giornale degli Italiani mantinham críticos que, assiduamente, escreviam sobre os recitais e concertos, propiciando não apenas o registro cultural da cidade, como também o indispensável estímulo ao iniciante, fator inalienável para a continuação que visa ao aperfeiçoamento. Inversamente ao crescimento desmesurado da cidade de Sáo Paulo, assistiu-se à total desativaçáo regular da crítica de concerto. Quando, na mais longínqua das raridades, algum jornalista pertencente aos quadros de uma empresa de jornais escreve sobre música, o faz quase scmpre despreparado.

O desmonte crítico jornalístico náo ocorreria por acaso. Houve o beneplácito dos manipuladores culturais ativos e de Ministérios passivos. Saliente-se que, no final dos anos 30 , um dos mais significativos pensadores musicais, Adolfo Salazar (1939), sem ter o contato com a genesis da mass communication, já preconizava um futuro impasse para as Artes, em geral, " (...) para um aumento em progressão geométrica do esforço criador, há uma resposta do aumento $\mathrm{em}$ progressão aritmética de sua eficácia no meio social: a perda na função conduz paulatinamente ao esgotamento". Este esgotamente ainda não teria chegado a termo, pois, em países já citados, a função musical erudita perdura estruturada em mecanismos próprios e costumeiros. A criação da música de concerto tem, inclusive, nas últimas décadas, correspondido no Brasil à ascensão geométrica, ratificando o posicionamento de Salazar. Inúmeros os compositores brasileiros que recebem encomendas e apresentam sistematicamente suas obras em festivais no Brasil e no Exterior, sob o silêncio tendencioso da imprensa manipulada nativa.

Dir-se-ia, num outro enfoque numérico, que o decréscimo da cultura musical de concerto junto à mídia verificou-se aritmeticamente, enquanto houve uma progressão geométrica para os espaços da cultura musical de massa junto aos órgáos de divulgação. Uma outra cultura, voltada à estatística dos números das mais díspares categorias - a essência essencial da existência do sistema - desconsidera quaisquer outros valores, acatando unicamente o que o lucro determina.

A mídia pareceria entender, pois, um dos aspectos mais transparentes da iniciativa privada, ou seja, a mutabilidade constante do produ- 
to a ser vendido. Essa assertiva indicaria que os manejadores da mídia, dela conhecendo os caminhos por vezes escusos, podem ter passado por empresas as mais diferenciadas e participado do esforço do marketing visando ao lançamento de produtos, entendendo-se do creme dental a um trator. Contaminado, esse agente que manobra a mídia, ou dela integrante, incensará hoje um músico do povão, o qual será fatalmente substituído amanhã. $O$ efêmero torna-se a égide a ser erigida. A reconscientização das massas pela mídia a cada mito construído, um problema facilmente resolvido pelo comunicador da imprensa escrita, falada e audiovisível. O mísico, despreparado para a função mas atirado para a encenação, dentro ou fora da açáo final - o espetáculo - evidencia-se um produto a ser usado, através do patrocínio da empresa do verdadeiro produto a ser vendido; e tanto um como outro freqüentam a mesma trilha da descartabilidade.

A ascensão geométrica de manifestaçóes esclerosadas, circunstanciais ou rejeitáveis, compartimenta o que o público deve entender por música popular. A esclerose ficaria por conta da perpetuação de músicos que produziram em torno dos anos 60 , criando a Bossa Nova, participando de Festivais de MPB, girando ao redor do Tropicalismo e que, hoje, não representam mais do que o pálido reflexo do que foram, permanecendo intensamente trabalhados pelos órgãos de comunicação, apesar ou em razão de tornarem-se a lembrança da lembrança de um passado sempre por eles rememorado. A mídia supóe passar para o público a renovaçáo, na realidade, a aparência longínqua.

Se a música sertaneja descaracterizada, ou a revisitação de baladas grotescamente amorosas são prestigiadas pelos órgãos de comunicação, considere-se, contudo, que o subterfúgio maior ficaria por conta das alteraçốes impostas ao rock, nas quais uma insanidade parece alastrar-se, rigorosamente ardilizada por interesses do Sistema. A tipificação amplamente divulgada pelos órgãos de comunicação apresentou a translucidez de referências que fazem limite com o desvario, mas deveriam servir à reflexão. Quando o líder de um grupo de rock, durante o último Festival em São Paulo dedicado ao gênero, confessou bem antecipadamente à sua apresentação, dirigir-se a um público idiotizado, a resposta ao pronunciamento resolveu-se através da presença maciça desse público idiotizado vestindo camisas com o logotipo do grupo. Imprensa, Rádio e TV deram espaços prioritários a todo o Festival c o que se ouviu foi a mediocrizaçáo do próprio rock exposta durante os referidos eventos. Os roqueiros internacionais, regiamente pagos, ainda destruíram os instrumentos que não sabem manipular e os aposentos que não fazem por merecer. As empresas patrocinadoras e a mídia náo teriam se mostrado 
igualmente idiotizadas, pois lá estiveram a divulgar amplamente o acontecido?

Nesse surrealismo, evidencia-se uma unidade final no que se refere ao interesse das empresas pelo lucro e pela estatística numérica ascendente, a desconsiderar a qualidade. São fatores convergentes ao estado atual: o despreparo nítido do manipulador da mídia que atende, na essência, ao desiderato do Império privado; a ditadura da informação, esse fator totalmente comprometido, quimera da liberdade que tanto apregoa; a aquiescência do Poder.

Presentemente, a divulgação pública ampla da música erudita verifica-se ou na evidência preferencial de repertório repetitivo tradicional, ou amalgamando in adendo a criação erudita e popular, praticados por músicos nacionais. Há por parte dos adeptos destas categorias repertoriais a possibilidade única da sobrevivência, a qualquer custo, junto aos meios de comunicação. Perde-se a referência da qualidade que, se buscada, correria o risco da inviabilização veicular.

Sob outro îngulo, orquestras promovem programaçóes faradnicas, não em repertório de concessão, mas na subserviência a interesses que atêm-se, da escolha dos intérpretes - por vezes integrantes do poder econômico e sem a qualidade necessária - ou em outra categoria de concessão, talvez a mais danosa, o total descuido por parte de diretores artísticos ou de regentes com a preparação dos músicos, resultando o anacrônico sonoro. Os integrantes das orquestras, tantos deles da maior competência, têm de sujeitar-se aos títeres, na angústia da preservação do emprego. Nenhum, mas nenhum desses eventos resistiria à audição crítica competente. Poderiam estes músicos dirigentes, assim como determinados intérpretes solistas voltados às concessóes, repetir os mesmos programas ou atuaçóes em países onde a música erudita é um costume natural? Certamente náo. O sucesso no Brasil resultaria em simulacro da contribuição à causa da cultura musical erudita, pois ao eleger a franca concessáo, esses músicos estáo nivelando, abissalmènte, um público que deveria ser respeitado em suas aspiraçóes, doravante mistificadas ou contaminadas pela ausência de referências.

Em diferenciado enfoque, o governo estimula outra espécie de concessáo, ao se interessar pela qualificação de centenas de jovens, sem o embasamento necessário, que freqüentam a Universidade Livre por ele criada, mas que leva à proliferaçáo dos eventos que mereceriam ser acompanhados. Neste caso, nâo teria havido o equívoco essencial desde o nome Universidade, rigorosamente anacrônico, pois não atende à menor observância aos princípios que norteiam o caminhar universitá- 
rio? A mídia não passaria a entender Universidade como uma palavra ambígua, equiparando a verdade do equívoco e provocando o incensamento da Universidade Livre, sem a preocupação de um refletir profundo? $O$ interesse pelo número de alunos e eventos não atenderia, sob outro prisma, a possibilidade de a Universidade Livre receber mais subsídios? Sob outro, por parte do governo, um impulso em direção às urnas?

Viu-se que o impasse hodierno da divulgação da música de concerto em todos os meios privados de comunicação, tem como causa o interesse da indústria cultural moderna, atenta à estatística numérica ascendente. Uma nova conscientização deveria ser entendida de cima para baixo. É possível que exemplos da veiculação e aplicação da música de concerto no exterior sensibilizem, um dia, dirigentes empresariais operando no Brasil, que permanecem surdos, até o presente, aos apelos a eles voltados. Não entendem esses executivos a magna importância do preservar e do fomentar bens culturais eruditos imprescindíveis. Há exceçōes voluntárias, ou, o que é lamentável, o mascaramento, com o fim único de incentivos nem sempre muito claros, através da doação. Não obstante, ficam perguntas que podem ter a força de denúncias: em que estágio cultural situa-se a média desses dirigentes? Estariam eles preparados para entender que a cultura musical erudita é harmoniosamente difundida em número considerável de países, os mais desenvolvidos economicamente? A maior parte desses empresários náo engrossaria a legião integrante e confessa da irracionalidade do Sistema? Os poderosos do governo, por sua vez, não estariam desinteressados pela cultura erudita, pela razão única de a mesma ser elitista, o que resulta em poucos votos?

Algumas soluçóes teriam de ser propostas: à fragilização dos conservatórios, que resulta na qualidade decrescente dos ingressantes nas Universidades, restaria a esta a criaçáo de escolas preparatórias ou de colégios técnicos, ou a manutenção dos existentes, que reteriam o aluno de música, previamente selecionado, no limiar da adolescência, preparando-o na profundidade e qualificando-o na competência para os vestibulares e, sobremaneira, para a profissão de mísico; a criaçáo de orquestras nos currículos da graduação, integradas pelos melhores alunos da escola preparatória e da própria graduação, o que, através de uma bolsa-trabalho realista, pudesse segurar na Universidade o precoce integrante de orquestras díspares, livrando-o do perigo do mal ajustamento profissional; a busca incessante, como desiderato primordial, pela competência do músico e do pesquisador, amparados pelo poder público, postulado inequívoco da diminuição numérica dos năo-competentes; a 
tentativa permanente junto ao governo-poder privado-mídia, na esperança de uma revisão de conceitos, o que resultaria em espaços justos para a cultura musical erudita; a difícil tarefa de convencer o jovem músico de que é viável a profissão almejada, objetivando, apesar do quase impasse atual, direcioná-lo a dedicar-se na competência sem a sujeiçăo do conceder.

Torna-se imperativo o combate, utilizando-se os instrumentos da qualidade. Instituiçóes governamentais destinadas ao fomento corroboram ainda, nesse subsistir, sem concessão. É-nos dado constatar que a indústria cultural moderna, tendo hoje a regência-mor da comunicaçáo audiovisual que equaliza, em todo o território nacional, gostos e costum̄es; práticas c modismos; aceitação ou rejeição; o que se deve ouvir, ver e ler; estabelecerá cada vez mais acentuadamente os seus tentáculos ditatoriais de padróes normativos. Mário Vargas Llosa observa, sobre a cultura audiovisual, que "diante desta toda-poderosa máquina popularizadora e niveladora do saber e da sensibilidade que o século XXI consagrará sem dúvida como a cultura representativa do nosso tempo, as diferenças que possam existir entre literatos e cientistas serão de ordem menor; ambos em todo caso, terão sido irmanados por sua condição de sobreviventes de uma época passada, de mantenedores de mentalidades e ofícios relegados pela história à periferia e à catacumba" (Vargas Llosa, 1993). Nesta crise das Artes como um todo, sem perspectiva de um vislumbrar a médio prazo, restará à Universidade - apesar de seus internos problemas -, como ilha da resistência ainda pouco contaminada, ou em outra metáfora, a catacumba pulsante dos que acreditam nessa persistência da esperança em direçáo ao descortinar.

\section{Nota}

1 Arquivo particular Maria Isabel Oswald Monteiro.

\section{Referências bibliográficas}

BOSI, Alfredo. Colônia, culto e cultura. In: Dialtetica da Colonizanfruo. Săo Paulo, Companhia das Letras, 1992, p. 11-63, 320.

JACOBY, Russel. Os villtimos intelecturis. São Paulo, Trajetória/Edusp, 1990.

SALAZAR, Adolfo. Musica y Sociedad en el siglo XX. Mexico, La Casa de España en Mexico, 1939, p. 151.

SOURIS, André. Conditions de ln musique et nutres écrits Belgique, Université de Bruxelles/CNRS, 1976, p. 109-110. 
VARGAS LLOSA, Mario. Cultura científica e cultura literária. São Paulo, Follıa de $S$. Paulo, Ilustrada, 24 jan. 1993, p. 3.

\title{
Resumo
}

O ensino musical do Brasil Colónia à atualidade. A decadência dos conservatórios. A música na Universidade: graduação e pós-graduação; publicaçōes; gravaçôes. A performance musical e a pesquisa, dentro e fora da Universidade. Progressōes da cultura musical erudita: aritmética (decrescente) e geométrica (ascendente). Governo (voto), iniciativa privada (lucro), mídia (massa receptiva): inter-relacionamento pragmático resultando o desmonte da cultura musical erudita. Impasse da crítica musical. Eventos internacionais no Brasil e a malversação de verbas. Festivais de música: comparações. Músico brasileiro: sobreviver na concessăo ou resistir na qualidade? Despreparo cultural do homem público, do empresário e do agente cultural. A Universidade como refúgio da cultura musical erudita.

\begin{abstract}
The musical training from Colonial Brazil to the present. The fall of the conservatory. The University: under graduate musical studies and graduate studies; publications; recordings. The musical performance research within and out of the University. Arithmetic progression (descending) of the erudite musical culture and geometric progression (ascending) of the mass musical culture. Government (vote), private iniciative (profit), media (mass reception): pragmatic interrelations, resulting in the dismanting of the erudite musical culture. Check of musical critique. International events in Brazil and misuse of funds. Musical festivals: comparisons. Brazilian musicians: surviving by catering to the market or insisting on quality? Cultural dispreparation of the politician: Business man and musical manager. The University as refuge of the erudite musical culture.
\end{abstract}

José Eduardo Martins, pianista e intérprete, ć chefe do departamento de Música da Escola de Comunicaçōes e Artes (ECA) da USP. Escreveu "O som pianístico de Claude Debussy" e tem ensaios publicados nos" Cahiers Debussy" do Centre de Documentation Claude Debussy de Paris. Desde 1978 realiza a edição crítica de significativa parcela da criaçăo de Henrique Oswald. Deste compositor gravou 5 Lps. É editor da "Revista Música", do departamento de Música da ECA-USP.

Aula Magna proferida pelo autor no Anfiteatro de Convençōes e Congressos da USP no dia 4 de março de 1993. 